эксперимента, математический, статистический, социологический методы;

- частные методы (вырабатываемые юридическими науками и используемые только в этих науках): формально-юридический метод, сравнительно-правовой метод [1, с. 13].

Резюмируя все вышеизложенное, можно констатировать следующее:

1) в научных кругах нет единой общепринятой точки зрения касательно классификации методов познания государственно-правовых явлений;

2) по нашему мнению теория государства и права как юридическая наука должна использовать все множество методов научного познания, поскольку выступает своеобразной азбукой юриспруденции, непосредственно формирует юридическое мировоззрение и способствует повышению уровня правосознания и правовой культуры в обществе и государстве;

3) с нашей точки зрения вопросы, связанные с методологией правовой науки, нуждаются в дальнейшем комплексном рассмотрении и анализе с позиции систематизации имеющихся теоретико-правовых знаний в данной сфере, а также дальнейшего совершенствования юридической деятельности в свете применения правовых знаний на практике.

$$
* * *
$$

1. Бялт В. С. Теория государства и права в схемах: Учебное пособие. - М.: Издательство Юрайт, 2020.

2. Керимов Д. А. Методология права: предмет, функции, проблемы философии права. М., 2015.

3. Комаров С. А. Общая теория государства и права: Учебник, 8-е изд. дополн. - СПб.: Издательство Юридического института (Санкт-Петербург), 2011.

4. Лебедев С. А. Методология научного познания: Монография. - М.: Проспект, 2018.

5. Марченко М. Н. Теория государства и права: Учебник. - 4-е изд., перераб. и доп. - Москва: Проспект, 2019.

6. Нерсесянц В. С. Общая теория права и государства: Учебник. - М.: Норма: ИНФРА-М, 2019.

7. Ромашов Р. А. Теория государства и права. - СПб.: Питер, 2009.

8. Спиридонов Л. И. Теория государства и права: Учебник / под ред. В. П. Сальникова. - СПб.: Фонд «Университет», 2004.

9. Сырых В. М. Понятие, структура и виды правовых исследований // Методологические проблемы юридической науки: Сборник материалов семинара, посвященного 10-летию кафедры теории и истории государства и права ЮУрГУ. Челябинск, 2011.

10. Теория государства и права: Учебник для бакалавров / под ред. В. К. Бабаева. - 6-е изд., перераб. и доп. - М.: Издательство Юрайт, 2019.

11. Черданцев А. Ф. Теория государства и права: Учебник для вузов. - М.: Юрайт, 2010.

\title{
Висарханова А.М. \\ Понятие взаимодействия следователя с органами дознания при расследовании преступлений
}

Ростовский филиал ФГБОУ ВО «Российский государственный университет правосудия»

doi: 10.18411/lj-04-2021-221

(Россия, Ростов-на-Дону)

Научный руководитель Демидченко Ю.В.

\section{Аннотация}

В статье рассматривается вопрос взаимодействия следователя с органами дознания. Анализируются определения различных авторов на понятие «взаимодействия следователя с органами дознания» и исследуются нормы действующего законодательства по рассматриваемому вопросу. Называются отличительные особенности и дается авторское определения взаимодействия. Рассматриваются процессуальные и непроцессуальные формы взаимодействия. 
Ключевые слова: уголовное судопроизводство, расследование и раскрытие преступлений, следователь, органы дознания, совместная деятельность, взаимодействие.

\section{Abstract}

The article deals with the issue of interaction between the investigator and the bodies of inquiry. The definitions of various authors on the concept of "interaction of the investigator with the bodies of inquiry" are analyzed and the norms of the current legislation on the issue under consideration are examined. Distinctive features are named and the author's definition of interaction is given. Procedural and non-procedural forms of interaction are considered.

Key words: criminal proceedings, investigation and disclosure of crimes, investigator, inquiry bodies, joint activities, interaction.

Несмотря на то, что в системе правоохранительных органов России, выделяются следственные органы, специально уполномоченные вести расследование и раскрытие преступление, следует констатировать, что для достижения ощутимых результатов в борьбе с преступностью необходима более эффективная работа по выявлению преступлений, предполагающая более высокий уровень взаимодействия органов предварительного следствия и органов дознания.

Следует отметить, что сегодня наблюдается отсутствие единства подходов к определению понятия взаимодействия следователя с органами дознания. Так, по мнению Х.Д. Хошимова, «взаимодействие - это согласованная по целям и задачам деятельность следователей с оперативными сотрудниками, направленная на предотвращение, раскрытие, полное и объективное расследование преступлений и привлечение виновных к уголовной ответственности» [6, с. 89].

А.Х. Хорхоруни, определяет взаимодействие следователя и органов дознания как «основанную на законе, ведомственных и межведомственных нормативных актах, согласованную по месту, времени и цели, совместную деятельность следователя и органов дознания, направленное на достижение задач уголовного судопроизводства» [5, c. 79].

По мнению Н.С. Бурнашева взаимодействие следователя с органами дознания представляет собой «основанную на законе и подзаконных актах совместную и скоординированную деятельность следователей с сотрудниками уголовного розыска и других служб ОВД, осуществляемую в целях успешного раскрытия, расследования и предотвращения преступлений» [3, с. 204].

И.Ф. Герасимов и Е.В. Цыпленкова определяют взаимодействие органов предварительного следствия и дознания как «правильное сочетание и эффективное использование присущих каждому из этих органов полномочий и методов работы, основанных на законе, направленных на раскрытие, расследование и предупреждение преступлений» [3, с. 72].

Более полный подход к определению понятия взаимодействия был предложен Р.С. Белкин, который определил, что «взаимодействие субъектов доказывания является одной из форм организации расследования преступлений, которая заключается в правовом взаимодействии следователя с органом дознания, согласованном по цели, месту и времени и осуществляемом в пределах их компетенции с целью полного и быстрого раскрытия преступлений, всестороннего и объективного расследования уголовного дела и розыска скрывающихся преступников, похищенных ценностей и других существенных по делу предметов» [2, с. 31].

Анализ действующего законодательства и мнений ученых по вопросам взаимодействия следователя с органами дознания позволили выделить следующие характерные (отличительные) особенности такого взаимодействия: 
во-первых, взаимодействие основывается на законодательных (УПК РФ, ФЗ «Об оперативно-розыскной деятельности», Ф3 «О полиции» и др.) и подзаконных нормативных актах;

во-вторых, представляет собой совместную деятельность субъектов;

в-третьих, данная деятельность носит плановый характер;

в-четвертых, согласованность между участниками взаимодействия в части целей, места и времени;

в-пятых, в процессе осуществления взаимодействия необходимо обеспечить эффективную расстановку сил и всестороннее использование методов и средств следствия и дознания;

в-шестых, следователь и сотрудники органов дознания не подчиняются друг другу и организационно независимы друг от друга;

в-седьмых, каждый из участников взаимодействия имеет свою роль, свою задачу, компетенцию (полномочия) для решения задач в рамках осуществляемого взаимодействия.

в-восьмых, ведущая, организующая роль в этой деятельности принадлежит следователю, поскольку именно он несет ответственность за результаты расследования уголовного дела;

и, наконец, в-девятых, данная деятельность направлена на достижение назначение уголовного судопроизводства и решение возникающих проблем.

Взаимодействие следователя с органами дознания складывается из различных связей и взаимоотношений между ними, которые широки и разнообразны. Конкретные способы и порядок этих связей выражены в определенных формах. В современных условиях, с учетом положений действующего законодательства, совместная работа следователя с органами дознания - оперативными подразделениями может осуществляться в двух основных формах: процессуальной и непроцессуальной (организационной).

Процессуальные виды взаимодействия являются исчерпывающими и перечислены в ст. 38 УПК РФ [1]. К ним относятся следующие:

1) исполнение органами дознания письменных поручений следователя о проведении оперативно-розыскных мероприятий;

2) исполнение органами дознания письменных поручений следователя о проведении производстве следственных действий;

3) исполнение органами дознания постановлений следователя о задержании, изгнании, задержании, приводе, об аресте, о производстве иных процессуальных действий;

4) содействие органами дознания следователю при производстве процессуальных действий.

Согласно ч. 1 ст. 152 УПК РФ следователь может поручить производство следственных или разыскных действий в другом месте органу дознания, который обязан выполнить поручение следователя в срок не позднее 10 суток.

Следует отметить, что следователь может давать поручение о производстве не всех следственных действий. Некоторые являются лишь прерогативой следователя, по сложившейся следственной практике, хотя на это и нет прямого указания в законе.

Непроцессуальных видов взаимодействия следователя с органами дознания гораздо больше, они не отражены в УПК РФ. На практике наиболее распространенными являются: обмен информацией, взаимные консультации по отдельным вопросам, выполнение заданий, участие в тактических операциях, совместное изучение и оценка имеющихся материалов раскрываемого дела. Могут быть и другие способы непроцессуального взаимодействия.

Названые выше отличительные особенности взаимодействия следователя с органами дознания позволяют дать определению такому взаимодействию: «- это основанная на законе и подзаконных актах совместная деятельность не подчиненных 
друг другу органов, обеспечивающая эффективное расстановку сил, комплексное использование методов и средств, направленных на решение проблем уголовного судопроизводства, с ведущей и организующей ролью следователя и четким разграничением компетенции участников взаимодействия».

$$
* * *
$$

1. Уголовно-процессуальный кодекс Российской Федерации от 18.12.2001 № 174-Ф3 // Собрание законодательства РФ. 24.12.2001. № 52 (ч. І). Ст. 4921.

2. Белкин Р.С. Криминалистическая энциклопедия. М., 1997.

3. Криминалистика: учебник / Под ред. А.Г. Филиппова. - М.: Юрайт, 2020.

4. Криминалистика: учебник / Под ред. И.Ф. Герасимова, Л.Я. Драпкина. - М., 1994.

5. Хорхоруни А.Х. Взаимодействие органов дознания и предварительного следствия при расследовании преступлений в Вооруженных Силах Республики Армения: Дис. ... канд. юрид. наук. - М., 2004.

6. Хошимов Х.Д. Взаимодействие следователя органов внутренних дел и милиции при расследовании уголовных дел: по материалам Республики Таджикистан: Дис. ... канд. юрид. наук. - M., 2009.

\section{Вырвина В.В. \\ Понятие и система органов местного самоуправления Российской Федерации}

Брянский филиал РАНХиГС

(Россия, Брянск)

doi: 10.18411/lj-04-2021-222

\section{Аннотация}

Статья посвящена определению содержания основных понятий и раскрытию системы органов местного самоуправления Российской Федерации. Автор осуществляет анализ теоретических и практических проблем правового регулирования организации местного самоуправления, указывая на особенности деятельности органов местного самоуправления.

Ключевые слова: орган местного самоуправления, представительный орган, публичная власть, полномочия, должностное лицо, муниципальное образование.

\section{Abstract}

The article is devoted to defining the content of the basic concepts and revealing the system of local government of the Russian Federation. The author analyzes the theoretical and practical problems of legal regulation of local government organization, points out the peculiarities of local government.

Key words: local authority, representative body, public authority, authorities, official, municipality.

Конституцией Российской Федерации установлено, что единственным источником власти в Российской Федерации (далее - РФ) является ее многонациональный народ, который осуществляет свою власть непосредственно, а также через органы государственной власти и органы местного самоуправления. Местное самоуправление является одной из основ конституционного строя РФ. В качестве наиболее приближенной к населению власти местное самоуправление обеспечивает защиту тех интересов граждан, которые основаны на совместном их проживании на определенной территории.

Термин «орган местного самоуправления» относится к конституционным терминам - он используется в статьях 3,12,15, 24, 32, 40, 46, 97, 130, 131, 132 Конституции РФ. В Федеральном законе №131- Ф3 определение этого термина изложено в следующей редакции: органы местного самоуправления - избираемые 